\title{
A Review on Analysis and Design of Precast Structures
}

\author{
Aman Agrawal ${ }^{1}$, S.S. Sanghai ${ }^{2}$, Kuldeep Dabhekar ${ }^{3}$ \\ $1_{\mathrm{M}-T e c h}$. Student, Structural engineering, G.H. Raisoni College of Engineering, Nagpur, India \\ 2Assistant professor, Department of civil engineering, G.H. Raisoni College of Engineering, Nagpur, India \\ 3 Assistant professor, Department of civil engineering, G.H. Raisoni College of Engineering, Nagpur, India
}

\section{Article Info}

Volume 8 Issue 2

Page Number: 345-350

Publication Issue :

March-April-2021

\section{Article History}

Accepted : 15 April 2021

Published : 24 April 2021

\section{ABSTRACT}

In India, maximum constructional activities are done using the ancient convectional cast in situ methods since a very long time. As the country is developing in a fast pace, the requirement for housing is escalating and thus the construction industries are also blooming rapidly hence demanding faster and better construction methods. This increased demand can be matched by using one of the modern technologies, pre-cast concrete method. Study of literature shows a number of precedence of precast concrete method over other methods of construction. Most importantly, its remarkable and desirable seismic behavior. Accordingly, a detailed review of the related literatures is discussed and also the pros and attributes of the precast concrete method are mentioned henceforth.

Keywords : Conventional Cast in Situ Method. Construction. Pre-Cast Concrete Method. Seismic Behavior

\section{INTRODUCTION}

In the developing era, the constitution of most of the industrial, residential and commercial constructions are based on the precast reinforced concrete (RC). Precast reinforced concrete method has numerous primacies over other; improved thermal properties, less man power, higher durability, improved standard of cast units, faster construction speed, shows social and environmental benefits, easy to understand, handle and apply. In India, precast concrete method is applied in very selective construction sites due to the misconceptions and lack of knowledge of the applicants. Also, this method lacks firm believes and trust which is the reason it is still not used in seismic regions. This brings our attention towards the need of enlightening the construction industries with proper knowledge and merits of precast method and the relations among the precast members. Studies need to be done in the field of precast buildings and methods. Review of several related literature is discussed in the upcoming details with the core purpose of developing awareness and motivating the use of precast in the coming generations of construction. 


\section{PRECAST STRUCTURE AND ITS TYPES}

Precast concrete is a construction product. The production of precast concrete is done using industrial methods (mass production for covering more construction sites in less cost) by settling the concrete in reusable molds and forms under controlled environments, then is transported to sites and lifted into places. It is mentioned in various studies [1-5] that precast structures are being given preferences over monolithic concrete structures across the globe because of its improved and desired qualities. In structures, durability is the key feature in ensuring a good performance in entire expected service period, so as the construction is able to resist actions which may deteriorate the materials. On the basis of load bearing system, precast structures can be classified into different systems: frame precast concrete system, slab column precast concrete system, and large panel precast concrete system, and mixed precast concrete system.

Large panel frame structures are multistory which consists of huge consoles of concrete placed in both horizontal as well as vertical ways to get an appropriate space enclosed for the rooms in the building. This horizontal and vertical console arrangement creates a box like structure that withstands gravitational loading, where placement of wall consoles is kept higher. On the other hand, precast concrete frames can be composed of either combination of column-beam or linear elements. This spatial column-beam combination has the primacy that the connecting faces can be fitted way from the regions of critical frame whereas in linear elements the connecting faces are at the junctions of the column, for the shear transfer from beam to column and construction ease the beam can be set on projected part at the columns. In spite of this, linear elements are usually preferred over spatial elements because of the trouble faced in formation, handling and erection [4].

\section{BENEFITS OF PRECAST STRUCTRURES OVER CONVENTIONAL CAST-IN-SITU STRUCTURES}

By the study of various literatures $[3,6-11,24]$ related to the pros of the precast structures, we can summarize the advantages of the prestressed precast structures over conventional cast-in-situ structures as:

- Precast structures require comparatively lesser construction time than conventional structures.

- Assurance of high-quality structures as the entire construction process is carried out in controlled environments.

- Precast concrete construction involves less man power.

- Speed of construction is comparatively higher in precast structures.

- Higher ductility of concrete than monolithic.

- These structures are featherlight in weight and also has shown much better thermal insulation

- Cracking moment gets improved by the application of the toping slab.

\section{BEHAVIOR OF PRECAST BUILDINGS DURING/AFTER EARTHQUAKES}

The uncertain seismic performance of the precast buildings during the earthquakes has been mentioned in the literature [1,12, and 13]. Studies showed that the precast buildings performed quite well with minor structural damages in the adverse conditions of earthquake in Northridge [14] and also in Chile [15]. On the contrary, studies done on the earthquake of Kocaeli and Duzce suggests that the defilement to these structures were caused mainly due to the poor connection between beam and column [16]. Further, the study on Emilia earthquake suggests the application of pin beam- 
column combination arrangement as the failure of the precast structure [17]. Also, during the earthquake in Turkey, it was observed that the major damages were seen in the joints of the precast buildings and it led to its global failure [18]. However, it is also seen that some of the welldesigned precast buildings performed excellent. Therefore, the usual observation from the literatures suggests that the failure of the precast structures is because the prefabricated buildings usually malfunction at the connections. So, it can be implied that the behavior or durability of the precast structure is largely influenced by the performance of the horizontal to vertical member connection.

\section{SEISMIC ANALYSIS OF PRECAST BUILDINGS}

When working on analysis of precast structures, especially on the grounds of seismic analysis, numerous studies by different authors $[2,12,13,19$, and 20] are been reviewed and can be summarized as: monolithic buildings (rigid structures) are efficient in resisting rotations, displacements and distortions because the beam-column connections are rigid. Whereas, in precast buildings the sternness in beam to column connections depend upon the pre-stressing force. In comparison to the monolithic buildings, the buildings with hybrid connections are more flexible. The bending moments in the hybrid beam to column joint arrangement are carryforward through flexural actions which is same as, to the traditional joint arrangement in the conventional buildings whereas the post-tensioning tendons induces frictional resistance which helps in the transfer of shear forces. Thus, the monolithic beam analogy explains that the precast joints combination is semi-sterned type connection. Since, the properties of precast concrete structures vary from conventional cast-in-situ structures, so, using the obtained internal forces from the analysis of the conventional structures to design the precast concrete structures will result in inappropriate designs.

\section{MODELLING AND DESIGNING OF PRECAST BUILDINGS}

In designing of the precast buildings, every type of loading and various conditions of restrains from casting to the end use of the structure need to be considered. The designing concept is primarily based on the build ability, standardization of the precast components and the economy factor. At the time of casting to final connection the stresses developed in the precast elements are censorious than the serviceload stresses. Due attention needs to be given at the time of stripping, storing, transporting and erecting of precast elements. The design of the precast elements should be such that they fulfill the tolerance requirements, also should provide the details of the effects of adverse fabrication. The contract documents shall quote the tolerance requirements along with the references of accepted standards, also the deviations, if any, from the accepted standards should be marked.

Khaja Rasool et al. [21] studied a project of Chennai as reference for understanding the designing, analyzing and capturing of the precast structures. He modeled the project in ETABS and analyzed the elements in their respective software. Similarly, Karthick M. [4] designed $\mathrm{G}+8$ storied precast concrete buildings with two different structural systems; one with large panel structure and other was framed structure with shear wall. The structures were then modeled and analyzed in ETABS software for dead, imposed, seismic, wind loads and load combinations. M.J.Gopinath et al. [22] studied a precast frame with two dimensional 3-bays $\mathrm{G}+5$ storied structure for lateral loading. He explained that the structure was strengthen by providing specially designed L-angels and bolts of steel by methods of welding and bolting joints in beam-tobeam connection and in beam-column junction. Lateral cyclic load was then applied on the frame until failure. The comparison of the result was carried out using ANSYS model. Yahya C. Kurama et al. [23] reviewed the researchers conducted since 1980's 
regarding the upgraded and advanced systems, designs, details and techniques of the precast structures for implication in the seismic zones. He also discussed the practical applications and code establishments of the moment frames, floor diaphragms, structural walls and bridges. Thus, he concluded that there is an improvement in the performance specially in seismic resistance of the precast structures due to the innovation of jointed connection in precast research thus, making it viable for use in high seismic zones. Later, the use of precast in housing with low costs in Indonesia was studied by H.N. Nurjaman et al. [24]. He describes that in Indonesia, the use of precast structure is highly accepted for building cost effective apartments, also these apartments have withstand high degrees of earthquake. Thus, the precast structures can contribute in developing houses and apartments in low budgets for rental and ownerships.

\section{CONCLUSION}

As per the analysis of various literatures, we can conclude that the precast concrete construction stand out against its on-site competitors because of its unparalleled quality, affordability, and longevity. There are various other factors which make precast concrete more reliable and a better method for regular construction. Its property of withstanding under seismic loading, cyclic loading and more similar loading makes it feasible for seismic and hazard prone zones. The precast elements are checked for quality control. Moreover, it involves a smaller number of working hands for construction and also takes less time and is very easy in installation and connection.

\section{REFERENCES}

[1]. Nadia Kamaruddin(\&), Chikai Watase, Mohammad Mahdi Raouffard, Luis Alberto Bedriñana, Kaiwei Zhang, and Minehiro
Nishiyama (2018), 'Durability and Seismic Resistance of an Aged Precast Prestressed Concrete Building Based on Field Inspections and Laboratory Testing'-Springer International Publishing AG 2018 D.A. Hordijk and M. Luković (eds.), High Tech Concrete: Where Technology and Engineering Meet, DOI 10.1007/978-3-319-59471-2_257

[2]. Vishal R. Deoda, Shrabony Adhikary · Ratnesh Kumar2 · Onkar G. Kumbhar(2019),' New Modelling Methodology for Seismic Design of Precast Structures and Performance Evaluation Considering Soil-Foundation System'- Arabian Journal for Science and Engineering (2019) 44:8305-8324

[3]. Ragavendra Holla, Siddhant Anant, Muzzamil Ali Muhammad, Aakash Periwal and Aakash Kapoor (2016), 'Time, cost, productivity and quality analysis of precast concrete system' International Journal of Innovative Science, engineering and technology, vol.3, No.5, pp.252-257.

[4]. Karthick M, Karthikeyan K (2015),' Comparative Studies on Different Types of Precast Structural Systems', - International Journal of Applied Engineering Research ISSN 0973-4562 Volume 10

[5]. Rinkesh Patel and Dr. Neeraj Sharma, 'Study of prefabrication in India' - International Journal of advanced research in Engineering, Science and Management, ISSN: 2394-1766.

[6]. Dinesh kumar and Kathirvel P (2015). 'Comparative study on prefabricated construction with cast in situ construction of residential building' - International Journal of Innovative Science Engineering and Technology, vol.2, No.4, pp.527-532.

[7]. Siva Priya and Senthamil Kumar. S (2016), 'Building cost comparison of precast vs conventional construction' - International Journal of Innovative Research in science, 
Engineering and Technology, vol.5, No.5, pp.8037-8044,

[8]. Akash lanke and Dr. D. Venkateshwarlu (2016), 'Design, cost and time analysis of precast and RCC buildings' - International Research Journal of Engineering and technology, vol.3, No.6, pp. 343-350.

[9]. Kyuman cho, Young su shin and Taehoon kim (2017), 'Effects of half precast concrete slab system on construction productivity', sustainability 2017, 9, 1268.

[10]. Iverson, J.K.; Hawkins, N.M.: Performance of precast/prestressed concrete building structures during northridge earthquake. PCI J. 39, 38-55 (1994).

[11]. Ghosh, S.K.; Cleland, N.M.: Performance of precast concrete building structures. Earthq. Spectra 28, S349-S384 (2012). https:// doi.org/10.1193/1.4000026

[12]. Ozturk, T.; Ozturk, Z.: Seismic damage observed on prefabri- cated industrial structures after 1999 earthquakes in Turkey and protecting measures. In: 14th World Conference on Earthquake Engineering, Beijing, China (2008)

[13]. Magliulo, G.; Ercolino, M.; Petrone, C.; Coppola, O.; Manfredi, G.: The Emilia earthquake: seismic performance of precast reinforced concrete buildings. Earthq. Spectra 30, 891-912 (2014). https:// doi.org/10.1193/091012EQS285M

[14]. Ozden, S.; Akpinar, E.; Erdogan, H.; Atalay, H.M.: Performance of precast concrete structures in October 2011 Van earthquake, Turkey. Mag. Concr. Res. 66, 543-552(2014). https://doi.org/10. 1680/macr.13.00097

[15]. Nadia Batalha, Hugo Rodrigues, Humberto Varum (2018),' Seismic performance of RC precast industrial buildings-learning with the past earthquakes'- Springer Nature Switzerland AG 2018
[16]. Matej Fischinger, Blaz ${ }^{\vee}$ Zoubek, and Tatjana Isakovic(2014),'Seismic Response of Precast Industrial Buildings'- Perspectives on European Earthquake Engineering and Seismology, Geotechnical, Geological and Earthquake Engineering 34, DOI 10.1007/978-3-319-071183_4.

[17]. R. K. Khare, M. M. Maniyar, S.R. Uma and V. B. Bidwai(2010),'Seismic performance and design of precast concrete building structures: an overview'- Journal of Structural Engineering Vol. 38, No. 3, August-September 2011 pp.272284

[18]. Ioannis N. Psycharis, Haralambos P. Mouzakis, and Panayotis G. Carydis,'Experimental Investigation of the Seismic Behaviour of Precast Structures with Pinned Beam-toColumn connections'- Role of Seismic Testing Facilities 345 in Performance-Based Earthquake Engineering, DOI 10.1007/978-94-007-19774_18, C Springer Science+Business Media B.V. 2012

[19]. Khaja Rasool Thagaragunta1, M. Helen Santhi2 (2015) 'Analysis and Design of a G+7storeyed Precast Building'- Civil Engineering Systems and Sustainable Innovations ISBN: 978-9383083-78-7

[20]. Gopinathan .M.J. and Subramanian .K (2013), 'High performance and efficiency of joints in precast members' - International Journal of Engineering and Technology, Vol.5, No.5, pp.4002-4009.

[21]. Yahya C. Kurama, Sri Sritharan, Robert B. Fleischman,Jose I. Restrepo, Richard S. Henry, Ned M. Cleland, S. K. Ghosh and Patricio Bonelli8 (2018),' Seismic-Resistant Precast Concrete Structures: State of the Art'- 2018 American Society of Civil Engineers.

[22]. Givssani .F and Mola .F (2006), 'Precast and cast in situ slab systems for residential building'.

[23]. Nurjaman H.N., Hariandja B.H and Sidjabat.H.R'The use of precast concrete 
systems in the construction of low cost apartments in Indonesia.

[24]. Dinesh kumar and Kathirvel P (2015). 'Comparative study on prefabricated construction with cast in situ construction of residential building' - International Journal of Innovative Science Engineering and Technology, vol.2, No.4, pp.527-532.

[25]. Kuabi ahmed AL and Hakob Avetisyan (2016), 'Reducing time and cost of construction projects by improving the properties of precast normal weight wall panels' science direct.

\section{Cite this article as :}

Aman Agrawal, S.S. Sanghai, Kuldeep Dabhekar, "A Review on Analysis and Design of Precast Structures", International Journal of Scientific Research in Science, Engineering and Technology (IJSRSET), Online ISSN : 2394-4099, Print ISSN : 2395-1990, Volume 8 Issue 2, pp. 345-350, March-April 2021. Available at doi : https://doi.org/10.32628/IJSRSET218267

Journal URL : https://ijsrset.com/IJSRSET218267 